УДК 781.22+785:780.647.2:785.2

DOI: 10.31318/2414-052X.2(51).2021.239390

СЕРГІЙ БЕДНИЙ

ORCID iD: 0000-0003-0150-3366, творчий аспірант кафедри баяна та акордеона Начіональної музичної академї України ім. П. І. Чайковського (Київ, Україна) s.bednii1707@gmail.com

\title{
ВПЛИВ ТЕМБРОВИХ ДЕТЕРМІНАНТ ОРКЕСТРОВОГО ТВОРУ НА ЙОГО ПЕРЕКЛАД ДЛЯ ДВОХ БАЯНІВ
}

\begin{abstract}
Проаналізовано сутність поняття «тембр» та технологію його утворення
\end{abstract} оркестровими інструментами та сучасним баяном. Розглянуто вплив тембрових детермінант оркестрового твору на його переклад для двох баянів. Обтрунтовано зміст модальних та інтенсивних властивостей тембрового звучання як оркестрових інструментів, так і двох баянів, які транслюються звуковими хвилями в просторі та часі. 3 'ясовано, щяо для досягнення максимальної імітаційної тотожності звучання двох баянів звучанню оркестрових інструментів автору перекладу необхідно враховувати «темброву вертикаль», «темброву горизонталь» та «темброву діагональ» оркестрового твору. Визначено алгоритм створення перекладу оркестрового твору для двох баянів, який складається зі сприйняття первинного музичного образу (звучання оркестрових інструментів) та уявного зіставлення 3 вторинним музичним образом (звучання двох баянів) на периептивно-когнітивному рівні мития. Описано кожну «операцію» цьвого алгоритму, яка відбувається завдяки асоиіативному ланцюжковому принципу і супроводжується пошуком уявних інваріантів перекладу оркестрового твору для двох баянів. Встановлено, щуо у процесі зіставлення первинних $і$ вторинних музичних образів характеристики тембрових звукових хвиль від трансляиії оркестрових інструментів залишаються незмінними, а інформація репрезентована з довгострокової пам'яті автора перекладу оркестрового твору для двох баянів - набуває рис варіативності. Висвітлено технологію пошуку найпривабливішого варіанту перекладу оркестрового твору для двох баянів. Описано методи досягнення насиченості тембрового звучання двох баянів аналогічної оркестровим інструментам. Продемонстровано приклади досягнення максимальної імітаційної тотожності тембрового звучання двох баянів тембровому звучанню оркестрових інструментів на основі сприйняття обертонів звучання оркестрових інструментів і їх трансформачії у звучанні двох баянів.

Ключові слова: тембр звуку, модально-інтенсивні властивості звукового тембру, просторово-часові властивості звукового тембру, оркестровий твір, оркестрові інструменти, дует баяністів.

Постановка проблеми... Історія жанру перекладень музичних творів 3 хорових творів на музичний інструмент бере початок 3 XVI ст. До перших спроб перекладень хорових творів для інструментального виконавства слід віднести зразки транскрипції хорових творів А. Вилларта (1490-1562), зроблених для лютні, найпопулярнішого інструменту того часу. Митці інструментального виконавства спрямовували зусилля на ознайомлення шанувальників музики зі 
світовими оперними, оркестровими та інструментальними шедеврами. Саме просвітницька мета лежала в основі створення митцями перекладень вокальної і оркестрової музики для музичних інструментів. Методика перекладу хорових, оперних і симфонічних творів для фортепіано, органу й інших інструментів базувалася тільки на фактурному та штриховому аспектах твору. Врахування тембрового аспекту при перекладі вокальних та хорових творів для інструментального виконавства (лютні, фортепіано, органа, скрипки тощо) унеможливлювала сама специфіка музичних інструментів, оскільки тембр звучання інструменту, для якого створювався переклад таких творів, був майже «статичний», тобто конструктивно не дозволяв використовувати великий спектр тембрального забарвлення звуків, хоча за рахунок виконавської майстерності інструменталісти прагнули досягти максимальної імітації звучання оркестрових інструментів.

3 появою багатотембрового баяна у виконавців 3'являється можливість опанування музичним репертуаром органних, скрипкових та фортепіанних творів. Переклад оркестрових творів для баянних митців становить найвищу складність, хоча темброва специфіка звучання сучасного баяна створює умови для максимальної імітації тембрів оркестрових інструментів. Особливо збільшуються творчі можливості при застосуванні не одного, а двох баянів. Саме тому простежується необхідність вивчення специфіки впливу тембрових детермінант оркестрового твору на його переклад для двох баянів.

Аналіз останніх досліджень і публікацій... Проблема впливу тембрових детермінант оркестрового твору на його переклад для двох баянів постала гостро в період появи багатотембрового готово-виборного баяна. «Тембр» (3 фp. timbre — дзвіночок, мітка, відмітний знак тощо) — це обертонові забарвлення звуку (Рагс, 2006). Предметність тембру чітко визначив Є. Назайкінський: «Тембровозвукова інформація є повною якісно-предметною характеристикою звукового джерела будь-якого акустичного випромінювача» (1988, с.32).

Тембровий аспект звучання оркестрових творів досліджували провідні музикознавці, такі як Б. Асаф’єв (1971), Г. Банщіков (1999), О. Трофимчук (2007) 
та інші. Зокрема, Б. Асаф’єв (1971), проаналізувавши оркестровий колорит, ввів таке поняття як «тембровий мелос». За його переконаннями, цей феномен створюється поєднанням тембрової динаміки і статики. У процесі аналізу законів функціональної інструментовки Г. Банщіков (1999) дійшов висновку, що просторову характеристику тембрового звучання оркестру. відображають «темброва вертикаль», «темброва горизонталь» та «темброва діагональ». У народно-оркестровій музиці О. Трофимчук (2007) розподілив тембри на натуральний, комбінований та ілюзорний, які утворюються в єдиному звучанні оркестру. С. Пономарьов (2011), досліджуючи роль тембру у формі музичного твору, ввів до музикознавства поняття «тембротектоніка», яке представляє тембровий план форми, що регулюється тембротектонічними закономірностями.

Звичайно, вихідні положення музикознавчих досліджень стосовно змісту понять «тембр», їх використання в оркестровому звучанні є слушними для подальшого вивчення. Натомість, у них відсутня інформація щодо впливу тембрових детермінант оркестрового твору на його переклад для двох баянів.

Мета дослідження полягає у висвітленні специфіки впливу тембрових детермінант оркестрового твору на його переклад для двох баянів. Для досягнення поставленої мети необхідно було вирішити такі завдання:

1) розглянути в музикознавчій літературі сутність поняття «тембр» та специфіку його утворення;

2) з’ясувати алгоритм побудови та зіставлення музичних образів в уяві автора перекладу оркестрового твору для двох баянів;

3) висвітлити технологію пошуку найпривабливішого варіанту перекладу оркестрового твору для двох баянів 3 урахуванням тембрового звучання як оркестрових інструментів, так і двох баянів.

Виклад основного матеріалу дослідження... Музикознавство на сучасному етапі розвитку цивілізації має суттєві надбання у вивченні змісту поняття «тембр», його видів (інструментальний, гармонійний, регістровий i фактурний), колоритів, динамічної ролі в оркестрі, впливу на форму твору тощо. Означені аспекти привертали увагу багатьох визначних науковців, композиторів 
та виконавців (Ф. Ліста, 1865; Б. Асаф’єва, 1971; С. Назайкінського, 1982; В. Москаленка, 2000; М. Манафової, 2010; Г. Банщікова, 1999; О. Трофимчука, 2007 та інших).

Детальне дослідження поняття «тембр» можливе тільки в умовах оркестрового звучання, оскільки на відміну від фортепіано, оркестр містить багато різних музичних інструментів, які в тембровому поєднанні між собою дають змогу проаналізувати та виявити нові утворення з різнобарвності звуків. Такий музичний інструмент як фортепіано, не має можливості відтворювати жодного $з$ тембрових елементів оркестрового звучання. Саме тому, Ф. Ліст, вказуючи на відмінність оркестрових тембрів від фортепіано, стверджував: «Фортепіано здатне передати за небагатьма винятками всі риси, всі образи найглибшого й серйозного музичного творіння і не залишає за оркестром ніяких інших переваг, окрім відмінності тембрів та масових ефектів...» (1865, с.232).

Сучасний баян, в порівнянні з фортепіано, являється багатотембровим музичним інструментом, який за своєю конструкцією спроможний імітувати звучання інструментів оркестру. Слід зауважити, що при перекладі оркестрового твору для одного баяна, вищезазначені темброві елементи (колорит, форма) мали б, також відтворюватися. Однак, конструкційна побудова багатотембрового баяна (зв'язаність двох клавіатур міхом) унеможливлює цей процес, оскільки формує бар'єр в динамічній гнучкості звучання його правого та лівого корпусу. Саме конструктивні можливості двох баянів дають змогу перевершити в тембровому аспекті можливості одного баяна, досягаючи максимальної тембрової тотожності зі звучанням оркестрових інструментів.

Алгоритм створення перекладу оркестрового твору для двох баянів передбачає процес сприйняття, обробки та уявного зіставлення тембрового звучання оркестрових інструментів і двох баянів на перцептивно-когнітивному рівні митця, а також відтворення бажаного/віднайденого варіанту в партитурі для двох баянів. Саме наукові досягнення психології в сфері сприйняття звуку та образного мислення надають змогу проаналізувати означений процес.

Сприйняття (від лат. perceptio) - складна система «прийому» i 
трансформації інформації, що забезпечує відображення об'єктивної реальності і орієнтування в навколишньому світі (Лекторський, 2010). Сприйняття тембрового звучання музичних інструментів автором перекладу оркестрових творів для двох баянів відбувається завдяки трансляції руху звукових хвиль у середовищі, які впливають на його слухові рецептори сенсорного регістру музичної пам'яті, i, практично, без обробки передаються до iï наступних функціональних систем (Юник, 2018). Темброве звучання оркестрових інструментів характеризується просторово-часовими, модальними та інтенсивними властивостями (Веккер, 1973).

Просторово-часовий аспект сприйняття тембрів музичних інструментів детермінується їх віддаленістю від автора перекладу оркестрових творів для двох баянів, акустичними даними середовища та характеристиками звукових хвиль, які містять основні тони та обертони. Він фіксує якісні та кількісні характеристики зовнішнього сигналу звукових хвиль, тобто їх герцовість.

Модальні властивості звучання оркестрових інструментів характеризують їх темброву відмінність в якісній специфічності, яка диференціюється за допомогою термінів: яскравий, різкий, матовий, гугнявий, пронизливий тощо. Однак, слід зазначити, що даний загальноприйнятий музичний опис тембрів не «збігається» 3 фізичними назвами тих якостей безпосередніх подразників (частота звукових хвиль, амплітуда, характер тощо), які відповідають цим модальним характеристикам. Наприклад, нота «ля» першої октави створюється 440-ма коливаннями голосника баяна в секунду. Фізичний аспект тут представлений у вигляді герцовості, а фіксована модальність — в самій назві ноти.

Кількісна характеристика тембрового звучання оркестрових інструментів виражається інтенсивністю звукових хвиль, тобто кількістю обертонів та їх амплітудою, що необхідно враховувати автору перекладу оркестрових творів для двох баянів, зокрема:

- якщо максимальну кількість обертонів оркестрових музичних інструментів автор перекладення трансформує у звучання двох баянів, то не 
тільки буде досягнута імітація тембрів оркестрових інструментів, а й «багатшим» стане тембр звучання двох баянів;

- для досягнення насиченості тембрового звучання двох баянів аналогічної оркестровим інструментам автор перекладу має спрямувати власну увагу на величину амплітуди обертонів тембрового звучання музичних інструментів оркестру та завдяки своїй уяві більшу їх кількість трансформувати у звучання двох баянів.

Загально відомо, що сила звучання оркестрових інструментів залежить від амплітуди коливань звукових хвиль і виражається в динаміці $(\boldsymbol{f}, \boldsymbol{p})$, а інтенсивність їх вібрацій - від фіксованої герцовості відтворення звуковисотних авторських позначень у нотному тексті. Тільки характер коливань звукових хвиль залежить від тембрів музичних інструментів. Саме тому, митцю при перекладі оркестрового твору для двох баянів необхідно керуватись як просторово-часовими, так і модально-інтенсивними властивостями звуків музичних інструментів, адже тільки вони підлягають обробці та зіставленню в його короткостроковій пам'яті. Віднайдений в уяві варіант для двох баянів трансформується в код оперативною іiі системою і переноситься до довгострокової пам'яті. Для «своєрідного зчитування» тембрової інформації означений код локалізується в загальній системі кодів, активується i репрезентується до короткострокової пам'яті автора перекладу оркестрового твору для двох баянів. В оперативній її системі відбувається декодування (Юник, 2018), що надає змогу митцю здійснювати зіставлення в уяві первинної інформації (темброве звучання оркестрових інструментів) 3 вторинною, яка відображає темброве звучанням двох баянів для пошуку бажаного варіанту. Слід зауважити, що фізичні характеристики звукових хвиль, які виражені у вигляді тембрів, обертонів, різної висоти звуків оркестрових інструментів (первинні ознаки інформації, що зберігаються в музичних сигналах від трансляції оркестрових інструментів), залишаються незмінними. Інваріантність тембрових характеристик можливих музично-звукових хвиль закладається перед початком «трансляції» вторинного сигналу, який при кожному надходженні до 
короткострокової пам'яті митця перекладу містить різну темброву, звуковисотну та динамічну інформацію. Інваріантність вторинного сигналу зберігається в структурі коду і в субстраті його мозку, тобто, інформаційний код, який містить первинний образ тембрового звучання оркестрових інструментів залишається незмінним, а інформаційний код вторинного образу (тембрового звучання двох баянів, що будується на основі інформації репрезентованої з довгострокової пам’яті) — набуває рис варіативності.

Сама структура коду в первинних і вторинних музично-тембрових образах забезпечує збереження їх просторово-часових, модальних та інтенсивних властивостей. При неточному сприйнятті таких властивостей первинного музичного образу в перцепції автора перекладу оркестрового твору для двох баянів спотворюється адекватність пошуку бажаного варіанту вторинного музично-тембрового образу. Як точне, так і неточне сприйняття узагальненої музичної інформації та відображення іiі в його короткостроковій пам'яті базується на автоматичній реакції безумовних рефлексів допсихічного рівня митця, а ретельне розпізнання висоти музичних звуків, визначення характеристики тембрів - на реакції умовних рефлексів психічного рівня (Сєченов, 1863). Тобто, він при прослуховуванні оркестрового твору сприймає тембри завдяки реакції безумовних рефлексів допсихічного рівня, а при аналізі колоритів оркестрових інструментів та їх співставлення в уяві з тембром двох баянів, беруть участь умовні рефлекси психічного рівня митця. Після реакції безумовних рефлексів автора перекладу оркестрового твору для двох баянів на надійшовшу музичну інформацію інваріантний сигнал вторинного образу потрапляє в сферу психічного сприйняття сигнал-коду, де відбувається поділ музичних образів на нижній та верхній діапазони (Павлов, 1927). Бар'єр між автоматичною реакцією безумовного рефлексу на сенсорний сигнал i спрямуванням уваги митця на сигнал перцептивний є опорною «лінією відліку», яка необхідна для визначення верхньої межі сенсорного діапазону. Такою «лінією відліку» зовнішнього модально-інтенсивного інваріантного сенсорного сигналу може бути будь-який звуковий фон, навіть різноманітний звуковий шум, 
який фіксується сенсорним регістром музичної пам'яті автора перекладу оркестрового твору для двох баянів і не переходить «межу» від відчуття до сприйняття. Для того, щоб перейти «звукову межу» відчуття, конкретний звук оркестрових інструментів мусить містити на порядок більші модальноінтенсивні звукові характеристики в порівнянні з аналогічними фоновими, тобто повинен виділятися з шумового фону. Саме тому, музичний тембровий звук оркестрових інструментів відноситься до верхньої «межі» сенсорного перцептивного сигналу, який має виділятися 3 фону і бути домінуючим в уяві митця. Однак, слід зауважити, що важливу роль у верхній «межі» перцептивного сигналу відіграє ступінь константності сприйняття тембрів оркестрових інструментів, оскільки діапазон максимальної адекватності просторово-часової та модально-інтенсивної характеристик пов’ язаний з їх стійкістю і збереженістю в умовах мінливого впливу безпосередніх звукових тембрових подразників.

Діапазон інваріантності модальних характеристик первинних і вторинних тембрових образів і $є$ інтервалом їх повної константності, а сама константність $€$ інваріантністю модальних характеристик перцепту та уяви митця в даному діапазоні. Таким чином, інваріантний сигнал у вторинних музичних образах відображає всі зміни висоти звуків і тембрів оркестрових інструментів первинних музичних образів та двох баянів, а також «відтворюється» по всьому діапазоні повної константності як у його перцепції, так і в його уяві. Слід зазначити, що вторинні музично-темброві образи мають рівень константності менший ніж первинні музично-темброві образи. Це залежить від міри точності відтворення модально-інтенсивних характеристик вторинних образів на які витрачається енергетичний потенціал автора перекладу оркестрового твору для двох баянів. Таким чином простежується закономірність: чим менше витрачається енергії митця у процесі уявлення тембрів двох баянів, тим меншу константність має вторинний музично-тембровий образ. Також на константність таких образів впливає термін збереження коду в довгостроковій пам'яті автора перекладу оркестрового твору для двох баянів. В його уяві вторинні музичнотемброві образи утворюються 3 накопиченого арсеналу тембрового звучання 
двох баянів, яке в даний момент не впливає на рецепторну поверхню слухового сенсора митця. Такі образи акумулюють в собі ознаки різних одиничних звукових тембрів (Веккер, 1973). На основі цих ознак в уяві автора перекладу оркестрового твору для двох баянів будується узагальнений музично-тембровий образ, який створює умови для переходу від перцептивно-образного до понятійно-логічного відображення структури цілої групи тембрових звуків, однорідних по будь-якій сукупності своїх ознак.

Первинні образи тембрового звучання кожного оркестрового інструменту за своїми тембровими властивостями по асоціативно ланцюговому принципу «нагадують» митцю загальне музичне забарвлення, яке властиве цілій групі оркестрових інструментів. На наступному етапі дії асоціативного ланцюжка відбувається узагальнення тембрового звучання групи оркестрових інструментів. Наприклад, тембровий звук труби, який пройшов шлях першосигнального константного сприйняття та зчитування 3 пам’яті автора перекладу оркестрового твору для двох баянів, «відтворюється» у вторинних образах митця та зіставляється по асоціативному ланцюговому принципу 3 іншим тембровим звучанням. В його мисленні звук труби спочатку асоціюється зі звучанням групи мідно-духових інструментів, а лише потім - 3 «дзвінким» та «пронизливим» тембром означеного інструмента.

Сучасний багатотембровий баян спроможний імітувати звучання флейти пікколо, кларнета, концертино і фагота, оскільки його конструкція має «ломану деку». Конфігурація тембрових перемикачів надає змогу імітувати звучання й інших інструментів, зокрема органа, клавесина, банджо тощо. Тембровий арсенал збагачується при наявності двох баянів, які в поєднані між собою утворюють темброву імітацію звучання оркестрових інструментів, наприклад: включення перемикачем «баяна 3 пікколо» створює умови для відтворення тембру звуку наближеного до тембру скрипки, «кларнета 3 фаготом» - до тембру саксофона. Слід зазначити, що тембр звучання голосів «виборної клавіатури» лівого корпусу сучасного баяна імітує тембр віолончелі. Звичайно, відтворити на баяні абсолютно тотожне темброве забарвлення звуків всіх 
оркестрових інструментів неможливо, але завдяки застосуванню двох багатотембрових сучасних баянів - збільшується частка як повної, так i імітаційної їх тотожності. Звичайно, це залежить і від маси одночасного звучання тембрів оркестрових інструментів. Зокрема, якщо в оркестровому творі виділяється тембр солюючого інструмента і присутнє лише незначне темброве забарвлення акомпанементу, то в автора його перекладу для двох баянів $\epsilon$ варіанти досягнення максимальної тотожності звучання оркестрових інструментів. Натомість, за умови застосування в оркестровому творі різнотембрового акомпанементу солюючому тембрально виділеному інструменту - змушує митця перекладу відшукувати варіанти для досягнення у звучанні двох баянів тільки імітаційної тотожності тембрального забарвлення звуків оркестрових інструментів (приклад 1).

Приклад 1.

С. В. Рахманінов. «Симфонічні танці» 1 ч. Фрагмент оркестрової nартитури.

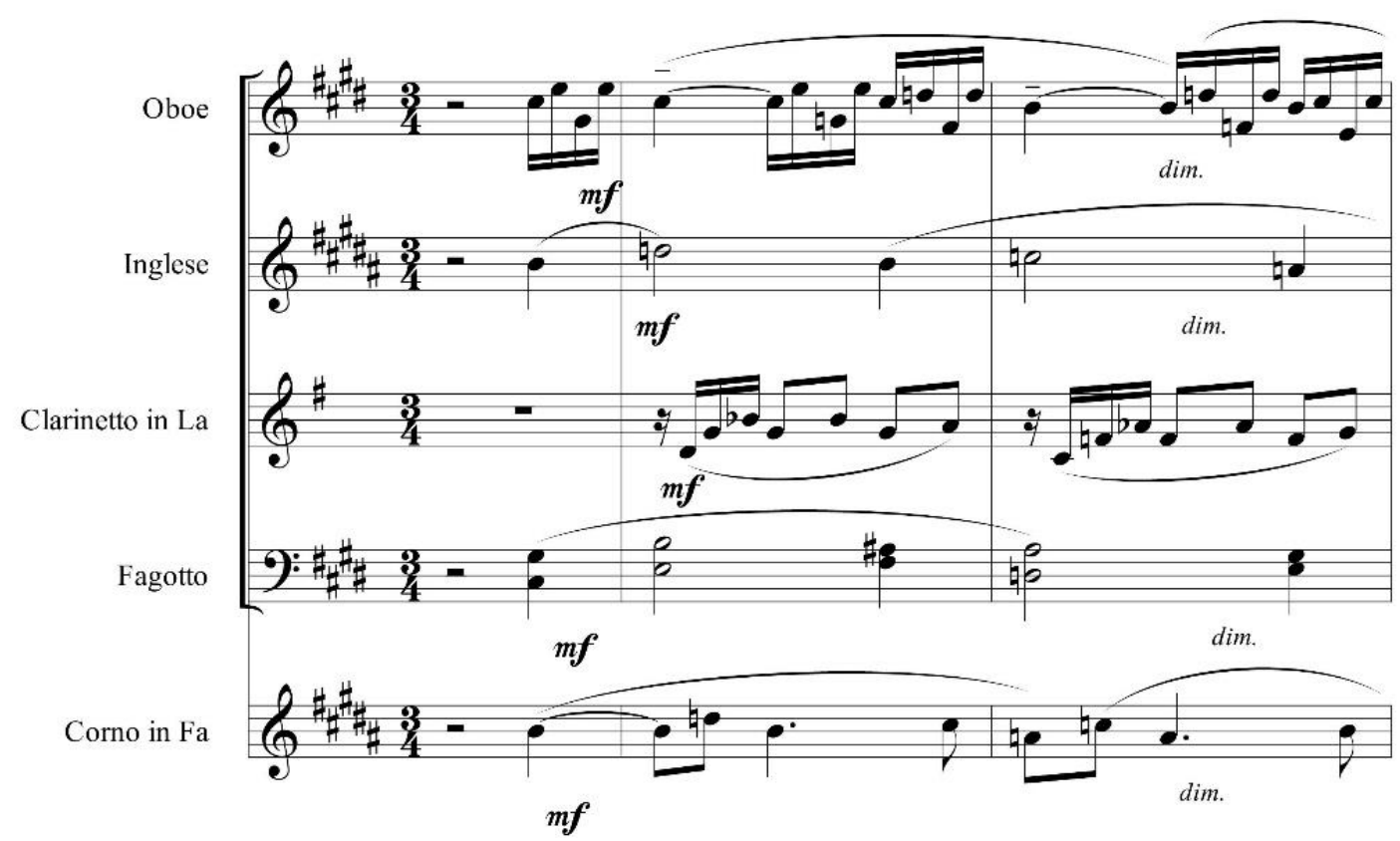

У першому варіанті перекладу фрагмента партитури С. В. Рахманінова «Симфонічні танці» для двох баянів (див. приклад 1.1) відображено технологію розподілу груп тембрового звучання оркестрових інструментів в нижньому, середньому та високому регістрах двох баянів. 
Приклад 1.1.

С. В. Рахманінов. Фрагмент з 1 ч. оркестрового твору «Симфонічні таниі». Перший варіант перекладу фрагмента оркестрової партитури для двох баянів.

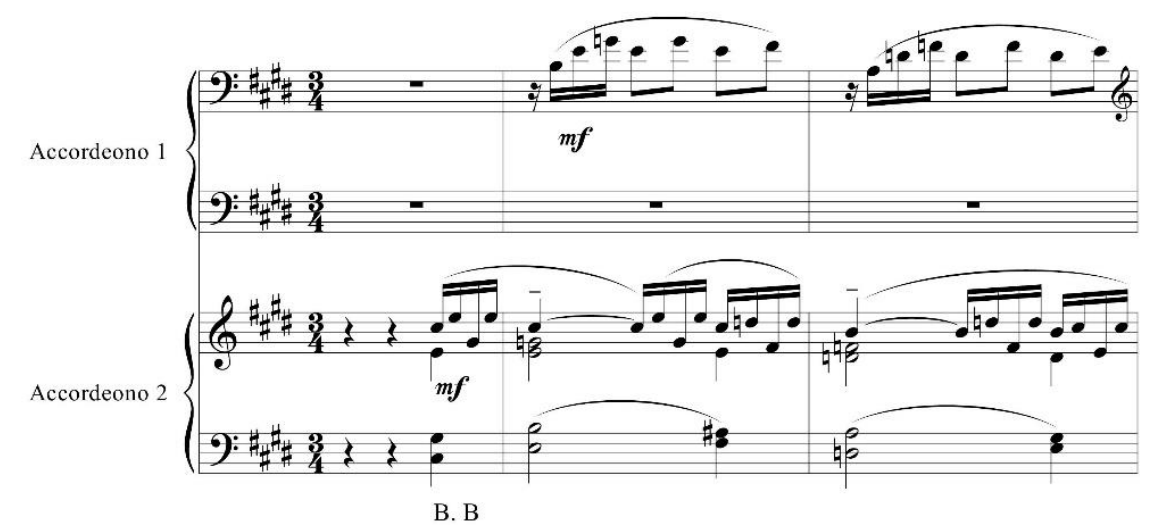

Другий варіант перекладу фрагмента партитури $\quad$ С. В. Рахманінова «Симфонічні танці» для двох баянів (див. приклад 1.2) надає змогу згрупувати тембри оркестрових інструментів і створити умови для динамічного підсилення їх колориту у звучанні двох баянів.

Приклад 1.2.

С. В. Рахманінов. Фрагмент з 1 ч. оркестрового твору «Симфонічні таниі». Другий варіант перекладу фрагмента оркестрової партитури для двох баянів.

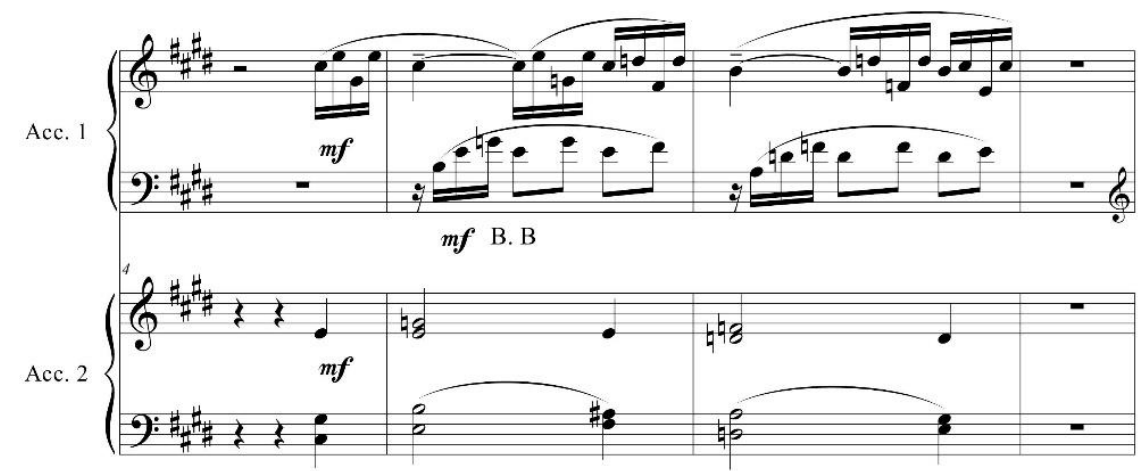

B. B

У цьому варіанті в автора перекладу означеного фрагмента для двох баянів простежується два способи досягнення тотожності звучанню оркестрових інструментів, а саме:

перший — «віддати» головні партії оркестрового твору першому баяну, а супровід - другому, що технічно полегшить веденням міху розмежувати динаміку звучання різних тембрів (див. приклад 1.2);

другий - розподілити більш рухомі головні партії оркестрових інструментів між правими клавіатурами двох баянів, а супровід — між лівими 
(див. приклад 1.3).

Приклад 1.3.

С. В. Рахманінов. Фрагмент 31 ч. оркестрового твору «Симфонічні танціі». Третій варіант перекладу фрагмента оркестрової партитури для двох баянів.

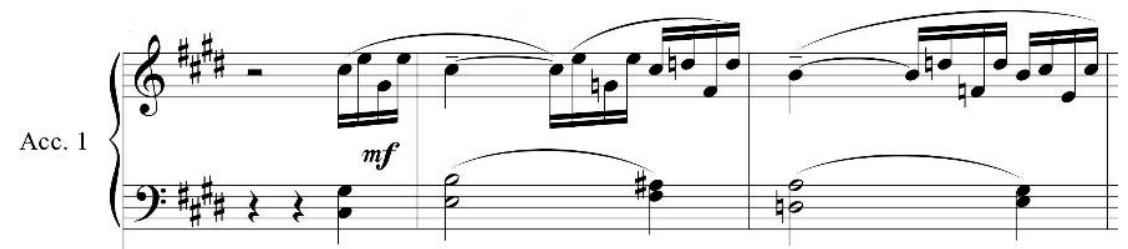

B. B

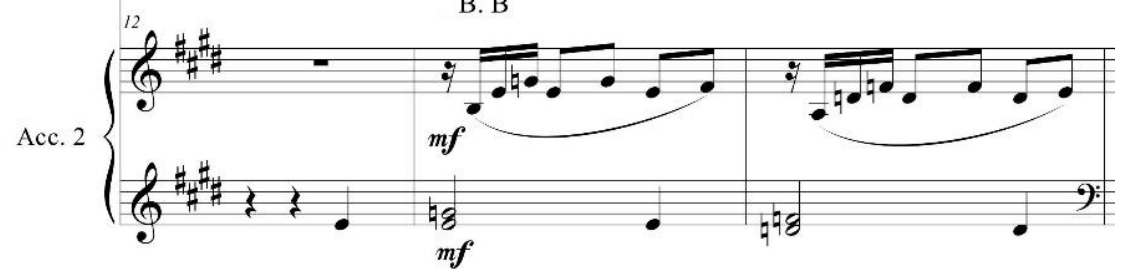

У прикладі 1.4 відображено варіант перекладу фрагмента 31 ч. оркестрового твору «Симфонічні танці». С. В. Рахманінова для двох баянів, який надає змогу досягти максимальної тотожності тембрового звучання двох баянів і тембрового звучання оркестрових інструментів.

Приклад 1.4.

С. В. Рахманінов. Фрагмент $з 1$ ч. оркестрового твору «Симфонічні таниіџ. Четвертий варіант перекладу фрагмента оркестрової партитури для двох баянів.

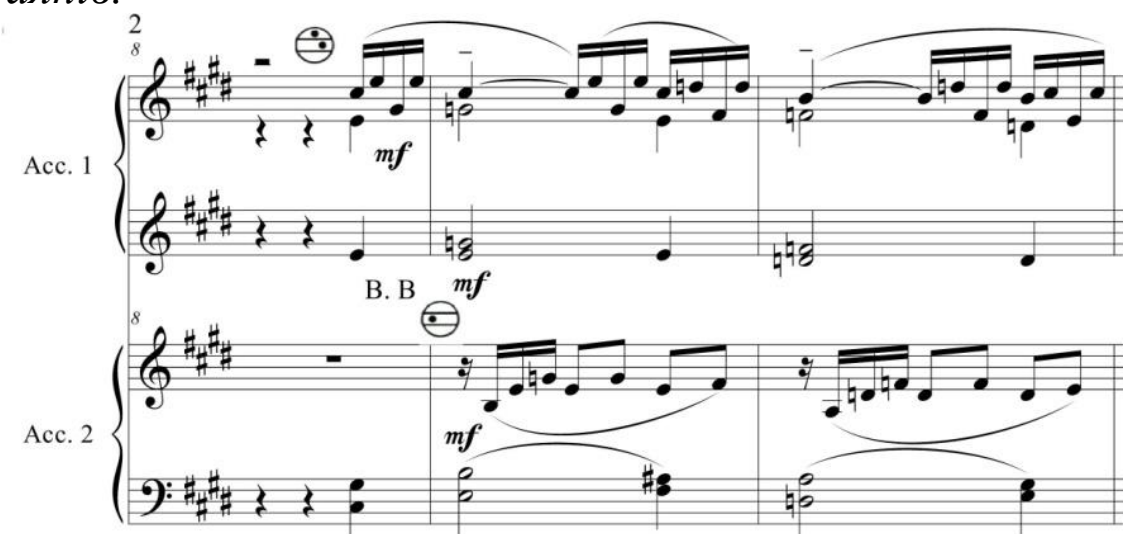

B. B

Така максимальна тотожність тембрового звучання двох баянів і тембрового звучання оркестрових інструментів у 4 прикладі досягається завдяки тому, що:

- тембр звучання оркестрового інструмента гобоя максимально імітується правою клавіатурою першого баяна 3 включенням аналогічного тембрового регістра у баяна $(\theta-$ гобой$) ;$

- тембр звучання англійського ріжка імітується звучанням лівої клавіатури 
першого баяна і дублюванням партії в його правій клавіатурі з включенням тембрового перемикача $\theta$, який надає змогу імітувати звук гобоя;

- тембр звучання кларнета максимально імітується правою клавіатурою другого баяна з включенням аналогічного тембрового регістра у баяна ( $\odot$ - кларнет);

- тембр звучання двох фаготів якісно відтворюються в тембровому звучанні нижнього регістру виборної клавіатури другого баяна.

Натомість, в означеному фрагменті партитури оркестрового твору С. В. Рахманінова «Симфонічні танці» партії валторни формує контрапункт у співзвуччі з англійським ріжком та фаготом. Зазначені оркестрові інструменти в тембровому звучанні між собою утворюють контраст, що спонукає автора перекладу цього твору для двох баянів відшукувати засоби імітації їх тембрів. Для цього (див. приклад 1.5) доцільно партію фагота виконати лівою рукою на виборній клавіатурі другого баяна в середньому регістрі, партію англійського ріжка та валторни — на виборній клавіатурі першого баяна і дублюванням у правій клавіатурі 3 тембром гобоя (@), адже тембр англійського ріжка наближений саме до цього тембру.

Приклад 1.5.

С. В. Рахманінов. Фрагмент з 1 ч. оркестрового твору «Симфонічні танціџ. П'ятий варіант перекладу фрагмента оркестрової партитури для двох баянів.

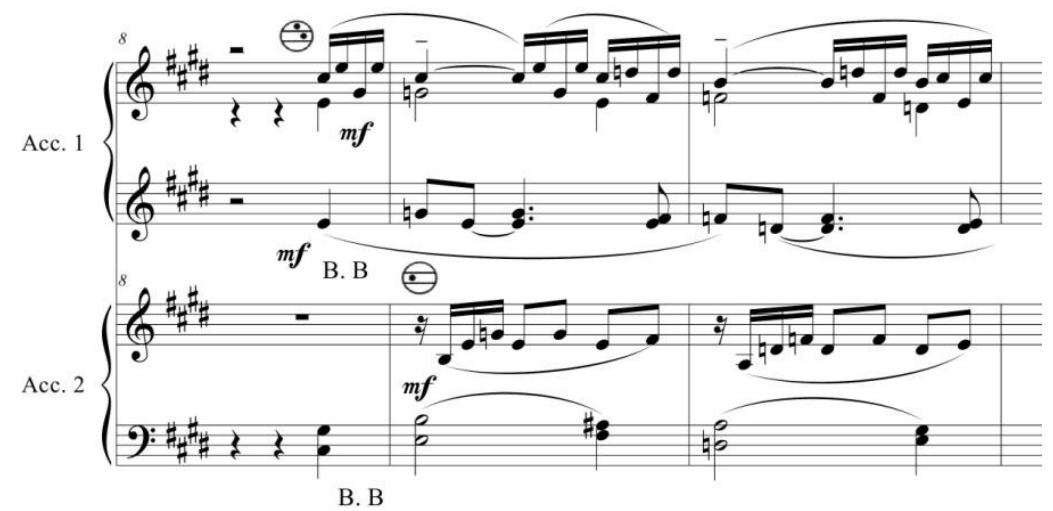

Отже, у кожному варіанті перекладу фрагмента 31 ч. оркестрового твору «Симфонічні танці» С. В. Рахманінова для двох баянів тембральне забарвлення звучання музичних інструментів виступає основною детермінантою впливу на прийняття творчого рішення. Також слід відзначити, що за наявності оркестрового туті, митець перекладу може відтворити більшу частину тембрів 
оркестрових інструментів в узагальненій тотожності, а меншу — в імітаційній. При пошуках найкращих варіантів його перекладу, окрім зазначених способів, необхідно враховувати вплив гармонії та фактури на тембр звучання двох баянів, оскільки їх тембр визначається складом співзвуччя, тобто залежить від гармонійного і інтервального поєднання окремих звуків, тісного або широкого їх розташування, що створює щільність, розрідженість або «порожнечу» звучання.

\section{Висновки.}

1. Тембр звучання оркестрових інструментів виступає основною детермінантою перекладу оркестрового твору для двох баянів. Для досягнення максимальної імітаційної тотожності звучання двох баянів звучанню оркестрових інструментів митцю перекладу необхідно враховувати «темброву вертикаль», «темброву горизонталь» та «темброву діагональ» оркестрового твору.

2. Алгоритм створення перекладу оркестрового твору для двох баянів складається зі сприйняття первинного музичного образу (звучання оркестрових інструментів) та уявного зіставлення з вторинним музичним образом (звучання двох баянів) на перцептивно-когнітивному рівні митця для віднайдення бажаного варіанту і його «відтворення» в партитурі для двох баянів. Кожна така «операція» відбувається завдяки асоціативному ланцюжковому принципу i супроводжується пошуком уявних інваріантів перекладу.

3. Темброве звучання як оркестрових інструментів, так і двох баянів, характеризується модальними та інтенсивними властивостями, які транслюються звуковими хвилями в просторі та часі. Досягнення максимальної імітаційної тотожності тембрового звучання двох баянів тембровому звучанню оркестрових інструментів відбувається завдяки сприйняттю обертонів звучання оркестрових інструментів і їх трансформації у звучанні двох баянів.

Перспективи подальших розвідок... Звичайно, викладена інформація не в повному обсязі розкриває всі аспекти поставленої проблеми. Ретельного розгляду потребує вплив фактурних детермінант оркестрового твору на його переклад для двох баянів. 


\section{Список використаної літератури і джерел}

1. Асафьев, Б. В., 1971. Музыкальная форма как проиесс. 2-е изд. Москва: Музыка.

2. Асафьев, Б. В., 1972. О музыке Чайковского. Ленинград: Музыка.

3. Банщиков, Г., 1999. Законы функциональной инструментовки. Санкт-Петербург: Композитор.

4. Веккер, Л. М., 1973. Психические проиессы. 1 том. Ленинград: Изд. ЛГУ им. А. Жданова.

5. Игнатченко, Г. И., 1984. О динамических процессах в музыкальной фактуре (на материале произведений украинских советских композиторов). Автореф. дисс. канд. искусствоведения. Киевская государственная консерватория им. П. И. Чайковского.

6. Лекторский, В. А., 2010. Новая философская энщиклопедия. Москва: Мысль.

7. Лист, Ф., 1865. Транскрипциии сочинений разных композиторов. Предисловие к переложению симфоний Бетховена для фортепиано. Перевод с немецкого В. Струкова. Рим.

8. Манафова, М., 2010. Тембр и темброколорит в современной музыкальной системе. Relga: научно-культурологический журнал, 14, с.212.

9. Москаленко, В. Г., 2000. Про художню функиію фактури в музиці. Київ: Науковий вісник Національної музичної академії України ім. П. І. Чайковського, 7, сс.56-65.

10. Назайкинский, Е. В., 1982. Логика музыкальной композищии. Москва: Музыка.

11. Назайкинский, Е. В., 1988. Звуковой мир музыки. Москва: Музыка, с.33.

12. Павлов, И. П., 1927. Лекции о работе больших полушарий. Москва; Ленинград: Государственное издательство.

13. Пономарев, С. В., 2011. К проблеме взаимосвязи тембра и формы в музыкальном произведении. Автореферат дисс. канд. искусствоведения. Московская государственная консерватория им. П.И. Чайковского.

14. Рагс, Ю. Н., 2006. Музыкальная энциклопедия. Москва: ДиректМедиа Паблишинг.

15. Сеченов, И. М., 1863. Рефлексы головного мозга. Ленинград: Академия наук СССР.

16. Трофимчук, О. Г., 2007. Темброва еволюиія в украӥнській народно-оркестровій музииі. Автореферат дис. канд. мистецтвознавства. Рівненський державний гуманітарний університет.

17. Фраенов, В. П., 2006. Музыкальная энциклопедия. Москва: ДиректМедиа Паблишинг.

18. Школяренко, С. И., 2017. Художественно-стилевые функиии фактуры в конщертных пьесах для фортепиано с оркестром Ф. Шопена. Дисс. канд. искусствоведения. Харьковский национальный университет искусств им. И. П. Котляревского.

19. Юник, Д. Г., 2018. Психологічні механізми сприймання авторського нотного тексту музичного твору виконавцями-інтерпретаторами. Науковий вісник Національної музичної академії України імені П. І. Чайковського, 123, сс.17-29.

\section{References}

1. Asaf'ev, B. V., 1971. Muzykal'naya forma kak protsess [Musical form as a process]. 2nd ed. Moskva: Muzyka. Muzyka.

2. Asaf'ev, B. V., 1972. O muzyke Chaikovskogo [About Tchaikovsky's music]. Leningrad:

3. Banshchikov, G., 1999. Zakony funktsional'noi instrumentovki [The laws of functional instrumentation]. Sankt-Peterburg: Kompozitor.

4. Vekker, L. M., 1973. Psikhicheskie protsessy [Psyche processes]. Vol. 1. Leningrad: Izd. LGU im. A. Zhdanova.

5. Ignatchenko, G. I., 1984. About dynamic processes in musical texture (based on the works of Ukrainian Soviet composers). Ph.D. in Art History. Abstract of Thesis. P. I. Tchaikovsky Kiev State Conservatory.

6. Lektorskii, V. A., 2010. Novaya filosofskaya entsiklopediya [New Philosophical Encyclopedia]. Moskva: Mysl'. 
7. List, F., 1865. Transkriptsii sochinenii raznykh kompozitorov. Predislovie k perelozheniyu simfonii Betkhovena dlya fortepiano [Transcriptions of works by various composers. Preface to the transcription of Beethoven's symphonies for piano]. Translated from German by V. Strukova. Rim.

8. Manafova, M., 2010. Tembr i tembrokolorit v sovremennoi muzykal'noi sisteme [Timbre and timbre color in the modern music system]. Relga: nauchno-kul'turologicheskii zhurnal, 14, p.212.

9. Moskalenko, V. H., 2000. Pro khudozhniu funktsiu faktury v muzytsi [On the artistic function of texture in music]. Naukovyi visnyk Natsionalnoi muzychnoi akademii Ukrainy imeni P. I. Chaikovskoho, 7, pp.56-65.

10. Nazaikinskii, E. V., 1982. Logika muzykal'noi kompozitsii [The logic of musical composition]. Moskva: Muzyka.

11. Nazaikinskii, E. V., 1988. Zvukovoi mir muzyki [The sound world of music]. Moskva: Muzyka, p.33.

12. Pavlov, I. P., 1927. Lektsii o rabote bol'shikh polusharii [Lectures on the work of the cerebral hemispheres]. Moskva; Leningrad: Gosudarstvennoe izdatel'stvo.

13. Ponomarev, S. V., 2011. On the problem of the relationship between timbre and form in a piece of music. Ph.D. in Art History. Abstract of Thesis. P. I. Tchaikovsky Moscow State Conservatory.

14. Rags, Yu. N., 2006. Muzykal'naya entsiklopediya [Musical encyclopedia]. Moskva: DirektMedia Pablishing.

15. Sechenov, I. M., 1863. Refleksy golovnogo mozga [Reflexes of the brain]. Leningrad: Akademiya nauk SSSR.

16. Trofymchuk, O. H., 2007. Timbre evolution in Ukrainian folk-orchestral music. Ph.D. in Art History. Abstract of Thesis. Rivne State University for the Humanities.

17. Fraenov, V. P., 2006. Muzykal'naya entsiklopediya [Musical encyclopedia]. Moskva: DirektMedia Pablishing.

18. Shkolyarenko, S. I., 2017. Artistic and stylistic functions of texture in concert pieces for piano and orchestra by F. Chopin. Ph.D. in Art History. Thesis. I. P. Kotlyarevsky Kharkiv National University of Arts.

19. Yunyk, D. H., 2018. Psykholohichni mekhanizmy spryimannia avtorskoho notnoho tekstu muzychnoho tvoru vykonavtsiamy-interpretatoramy [Psychological mechanisms of perception of the author's musical text of a musical work by performers-interpreters]. Naukovyi visnyk Natsionalnoi muzychnoi akademii Ukrainy imeni P. I. Chaikovskoho, 123, pp.17-29.

SERGEY BEDNYI

ORCID iD: 0000-0003-0150-3366,

Postgraduate Student at the Department of Button Accordion and Accordion at the P.I. Tchaikovsky National Academy of Music of Ukraine

(Kyiv, Ukraine)

s.bednii1707@gmail.com

\section{INFLUENCE OF TEMBER DETERMINANTS OF ORCHESTRA WORK ON ITS TRANSLATION FOR TWO BUTTON ACCORDIONS}

The essence of the concept of "timbre" and the technology of its formation with orchestral instruments and modern button accordion are analyzed. The influence of timbre determinants of an orchestral work on its translation for two button accordions is considered. The content of modal and intensive properties of timbre sound of both orchestral instruments and two button accordions, which are transmitted by sound waves in space and time, is substantiated. It was found that in order to achieve the maximum imitation identity of the sound of two button accordions, the author of the translation must take into account the "timbre vertical", "timbre horizontal" and "timbre diagonal" of the orchestral work. An algorithm for creating a translation of an orchestral work for two button accordions, which consists of the perception of the primary musical image (sound of orchestral instruments) and imaginary comparison with the secondary musical image (sound of two button 
accordions) at the perceptual-cognitive level of the artist is determined. Each "operation" of this algorithm, which occurs due to the associative chain principle and is accompanied by the search for imaginary invariants of the translation of an orchestral work for two button accordions, is described. It was found that in the process of comparing primary and secondary musical images, the characteristics of timbre sound waves from the broadcast of orchestral instruments remain unchanged, and the information represented from the long-term memory of the author of the translation of the orchestral work for two button accordions - acquires variability. The technology of searching for the most attractive variant of translation of an orchestral work for two button accordions is covered. Methods for achieving the saturation of the timbre sound of two button accordions similar to orchestral instruments are described. Examples of achieving the maximum imitation identity of the timbre sound of two button accordions to the timbre sound of orchestral instruments based on the perception of overtones of the sound of orchestral instruments and their transformation in the sound of two button accordions are demonstrated.

Keywords: timbre of sound, modal-intensive properties of sound timbre, spatial-temporal properties of sound timbre, orchestral work, orchestral instruments, duet of button accordionists.

Стаття надійшла до редакиії 5.02.2021 